\title{
SOCIAL ASPECT OF TIME MOVEMENT OF MATTER AS AN ELEMENT OF ORGANIZATION OF SOCIAL LIFE
}

\section{Guyvan P. D.}

\section{INTRODUCTION}

The question of time is very important worldview. From time immemorial, ordinary people, scientists and entire schools have been concerned with the essence of time, trying to understand its properties. Of course, this question is the subject of study of philosophical science, but it is relevant to other areas of knowledge. Therefore, other sciences, including legal sciences, are also interested in this issue. Time occupies a special place in the life of societies and each individual. This is one of the fundamental categories of the world around us, which concerns general concepts that express sensitive perception and its connection with reality. Awareness of events that occur in time means knowing being as such. The discontinuity of time and space has the reproduction in reality that material objects have a relative discreteness of their existence. In other words, there is a temporal and spatial differentiation of bodies. But the motion of objects is still continuous, it cannot be reduced to the sum of discrete moments. That is, time movement has a certain connection, there are no gaps in it.

The question of "what is time, what is the meaning of this phenomenon" is constantly of interest to scientists, from philosophical to apologists for classical and relativistic physics: they all tried to understand the meaning of time, to understand its nature and essential properties. This aspect is also important for representatives of legal science, although we must state that in the field of its attention this issue does not take up enough space. However, scientists who are concerned with the essential nature of time, have long noticed that its purely physical interpretation is quite narrow. In reality, time is something incomparable, more fundamental than the duration, moment or interval than anything that can be expressed by the position of the hands or the position of the lights in the sky. Addressing the universal process and taking into account social and cultural development, we should talk about the existence of time as a regulator of social relations, which has elements of historical, social and individual.

Social processes and phenomena, human activity, public policy, lawmaking and law enforcement occur over time. In other words, any social relations, including those regulated by law, are subject to temporary influence. They have a certain duration, sequence and temporal relationship. 
Time characterizes not only external to the observer phenomena, it is also inherent in the internal nature of man. Therefore, in modern science it is customary to emphasize not only the reality of purely physical manifestations of life, but also its socio-historical aspects. In fact, giving time only a physical interpretation as duration, term or period, it is not possible to cover all its multifaceted manifestations. No matter how objectively the course of time, its perception, determination of the influence on the state of matter, in the end, the study of temporal manifestations is possible only if this phenomenon is reflected in the human mind. After all, the existing order of processes covers the progress of society, community, and ultimately, the very lives of individuals.

Time characterizes not only external to the observer phenomena, it is also inherent in the internal nature of man. Thus, in modern science it is customary to emphasize not only the reality of purely physical manifestations of existence, but also the socio-historical aspects of it. In fact, giving time only a physical interpretation as duration, term or period, it is not possible to cover all its multifaceted manifestations. No matter how objectively the course of time, its perception, determination of the influence on the state of matter, in the end, the study of temporal manifestations is possible only if this phenomenon is reflected in the human mind. After all, the existing order of processes covers the progress of society, community, and ultimately, the very lives of individuals. Human activity, as well as its very existence occurs in time, any social relations, including those regulated by law, are subject to temporal influence. Therefore, the study of the perception of time, taking into account various subjective factors is of great importance. As A. Camus rightly noted, time passes slowly, when you follow him, he feels the surveillance. But the temporal flow enjoys our inattention. It is even possible that there are two times: the one we follow and the one that transforms us.

\section{General idea of the sociological aspect of the time course}

In the scientific literature of recent decades, one can often find references to "legal", "cultural", "pedagogical" and other space, which indicates attempts to establish some fundamental and, at the same time, elementary ontological structures for the implementation of specific human activities. In terms of philosophical and methodological analysis, these characteristics are not a separate space and time, but the facets and sides of the complex of social chronotope, which ensures the reproducibility and internal coherence of society. Therefore, it is logical to consider in the sociological perspective of space and time as one of the phenomena that characterizes the course of processes, relationships and interdependencies in the social sphere, 
hierarchically interconnected ${ }^{20}$. Time coincides regardless of any external circumstances. Be that as it may, the ability of man to influence the general objective course of time is obvious. The concept of "social time" was introduced in the scientific literature. In fact, this is the understanding of this philosophical category, which is associated with the influence of man on the objective course of time ${ }^{21}$. Social time and space are forms of conscious social existence. This, of course, does not mean that they depend on the will and consciousness of man. Spatial-temporal connections are made objectively, but on the basis of human activities. Thus, awareness of the content of social existence - human activity, leads to awareness of the forms of this existence - social space and time. Therefore, the time studied by all social disciplines, including jurisprudence, is called social time. Social time measures the duration of social processes and the dynamism of their change. First of all, this influence is manifested through the possibility of setting time limits for the existence of certain subjective rights and rules to adjust the course of certain terms. After all, a person's determination of the mechanism for calculating time, ie the order of subjective awareness of their duration, is also an important factor that confirms this effect. Therefore, the study of the peculiarities of the perception of time, taking into account various subjective factors, is of great importance. Man has a conscious attitude to time, he is able to coordinate their activities in certain periods, plan for the future, be aware of their past. In the ontological sense, social time is a necessary form of social life, which characterizes the real processes of human life, recording and regulating their activities. Within the scientific analysis of social time, personal-temporal issues are investigated, which relate to the temporal organization of an adult's consciousness, behavior during individual and group life and communication, which defines such a category as lifestyle ${ }^{22}$. In this case, each science studies these issues from its own point of view.

As V.V. Luts points out, the specificity of social time as a form of movement of social matter is that it is imprinted by the existing in society dialectical connection of objective and subjective, necessity and freedom. Social connections and relationships, constituting the content of social time, arise on the basis of the activities carried out by people. And, although the

20 Барковская А.Ю. Социологическая интерпретация категории «социальное пространство». Вестник Волгоградского государственного университета. Сер. 7. Филос. 2013. № 1(19). С. 54.

${ }^{21}$ Sorokin P., Merton R. Social time. A methodological and functional analysis. American Journal of Sociology. 1937. № 5. (V. 42). P. 615.

22 Ковалев В.И. Личностное время как предмет психологического исследования. Психология личности и время. Тезисы докл. и сообщ. Всесоюзной научнотеоретической конф. Черновцы : 1991. Т. 1. С. 6. 
spatio-temporal forms that mediate them arise objectively, the awareness of the last people in society becomes one of the important factors in the scientific management of social processes ${ }^{23}$. From the point of view of researchers, social time is, first of all, a social institution, a way of measuring and organizing real life, its development, change. As rightly noted by P.A. Sorokin, social time can (and should) be defined in its own coordinate system, as a change or movement of social phenomena through other phenomena, taken as a starting point ${ }^{24}$.

If we consider these issues from the point of view of the causal scientific model, we will see that it is as a result of personal experience of the defining relationships between the main events of life that psychological time is formed as an element of social time. Hence the determinism of human life, according to which not only previous events determine the next (determination of the past), but also subsequent goals and desired results determine previous actions (determination of the future). Therefore, the interaction of psychological categories of past, present and future is presented as the ratio of realized connections between events of chronological past, actual connections between events of past and future that continue, and potential connections between subsequent chronological events $^{25}$. Being further formalized as legal relations (legal relations), the new relationships move to the scope of regulation by appropriate legal mechanisms. F.K. Savigny once noted that in each legal relationship can be divided into two parts: first, the matter, ie the relationship itself, and, secondly, the legal definition of this matter. The first part can be called a material element of the legal relationship, or a pure fact in it, the second - a formal element, ie that which raises the actual relationship to the legal form $^{26}$. The forms of movement of matter that give certainty to the legal relationship, in the first place, include temporal factors that ensure the effectiveness of law. In constructing specific material relationships, the parties to the transactions, determining their content, take into account the temporal criteria of the respective subjective rights and obligations, most adequate to their own private or public (if the legislator sets deadlines) needs. And these needs can be determined taking into account the factor of

23 Луць В.В. Строки і терміни у цивільному праві : монографія. Київ : Юрінком Інтер, 2013. C. 8.

${ }^{24}$ Sorokin P., Merton R. Social time. A methodological and functional analysis. American Journal of Sociology. 1937. № 5. (V. 42). P. 58.

${ }^{25}$ Головаха Е.И., Кроник А.А. Понятие психологического времени. Категории материалистической диалектики в психологии / Под ред. Л.И. Анциферовой. Москва : Наука, 1988. С. 215.

${ }^{26}$ Савиньи Ф.К. фон. Система современного римского права. Т. I / Пер. с нем. Г. Жигулина; под ред. О. Кутателадзе, В. Зубаря. Москва : Статут, 2011. С. 458. 
social time ${ }^{27}$. As participants in various relationships in society and with each other, people not only learn, but also use time differently. Thus, we can conclude about the importance of human influence on the process of learning about nature through its connection with it.

All social and legal processes and relations proceed in only one direction - from the past to the future, passing "in transit" through the present. This direction of material phenomena is subjective and does not depend on the consciousness of people who perceive these processes. The growing influence of time on the development of social relations, including those of a legal nature, leads to the need for a broader scientific analysis of existing temporal categories, giving them greater efficiency and adequacy. Law, the rule-making process, and the social relations regulated by them also exist in time. They arise, change and cease during periods that have specific human temporal coordinates. Legal norms, in turn, determine the temporal parameters of certain material relations. The law often includes in the disposition of the norm such temporal factors as "timely", "early", "on time", "immediately", "statute of limitations" and so on. Within the existence of specific legal relations, the components of their content are also limited in time: the subjective rights and legal obligations of the participants. This provides a legal impact on the appropriate behavior of the subjects of social interaction.

In law, the time category is the term, ie the period in the objective course of time, chosen as a result of the willful act of people to establish the boundaries of lawful and desirable behavior of the parties. Establishing time limits for the exercise of civil rights and obligations provides an opportunity for appropriate actions by the parties to legal relations aimed at achieving socially desirable goals. Therefore, the temporal regulation of subjective rights and responsibilities is an important means of legal influence on the behavior of participants in public relations. The socio-legal nature and legal significance of terms determine the rules for their establishment and definition, which, in turn, affect the application of the provisions of the law on terms and create conditions for filling the mechanism of influence on public relations with specific content. Norms of private law are designed to regulate the relations that arise in order to satisfy the private interest, because it is necessary in every act $^{28}$. Thus, in civil relations, subjective rights and responsibilities are usually formed at the will of their bearers. Consequently, the setting of the duration is also determined by the subjects themselves as a

${ }^{27}$ Гуйван П.Д. Теоретичні питання строків у приватному праві : монографія. Харків : Право, 2014. С. 47.

28 Азімов Ч.Н Поняття цивільних правовідносин. Вісник Університету внутрішніх справ. 1999. Вип. 6. С. 19. 
result of the expression of their will. If the counterparties have not agreed on the terms of the relevant interaction, the temporal criteria of validity of their rights and obligations, enshrined in law (the so-called principle of application of dispositive rules) are used. And only occasionally does civil law resort to the imperative in regulating the duration of social relations. There is no doubt about the voluntary nature of the terms set by the participants in the civil substantive legal relations or by the competent law enforcement bodies. As a result of the willful and conscious legal actions of the subjects of law, the terms bear the imprint of the subjective, but, if they are established, they already exist objectively.

Deadline is a certain period of time. However, time moves in space and can not be imagined without it. Therefore, thinking about a specific period of time makes sense only in relation to the subject, the beginning and end of which it determines. In other words, outside the space of a certain phenomenon, the term loses all certainty. Thus, the legal term is an objectively existing relationship between the phenomena of the legal order, which manifests itself as a certain number of qualitative changes in legal phenomena, expressed in calendar time, occurring in a certain sequence with changes due to the impact of these phenomena on each other. which is reflected in human consciousness in the form of a certain number of hours, days, etc. We should agree with the description of terms provided by V.V. Luts: civil terms are a temporary form of movement of material legal relations, a form of existence and development of subjective rights and obligations that constitute their content. The expiration or expiration of the term is important not in itself, but only in conjunction with the actions of the subjects committed during its course. For example, the omission of the statute of limitations entails the rejection of the claim not simply because this period has expired, but because the plaintiff during its duration did not file a lawsuit to protect the infringed right ${ }^{29}$.

\section{Regulation of sociological time in the field of material turnover}

Forms of using time criteria in material relationships are chosen differently. But it is indisputable that the effectiveness of legal regulation in general depends on the right choice and reasonable establishment of the temporal component ${ }^{30}$. Modern society is increasingly reaching the appropriate level of awareness of the fact that law is a means of achieving stability and certainty of social relations. It should be aimed at taking into

\footnotetext{
29 Луць В.В. Сроки в гражданских правоотношениях. Правоведение. 1989. № 1. C. 40 .

${ }^{30}$ Шовкова О.В. Строки і терміни як категорії цивільного права. Проблеми законності. 2005. Вип. 74. С. 171.
} 
account the mutual interests of the parties, in particular in the field of material turnover. In this context, one of the defining directions of the development of law is the regulation of the terms during which the subjects can exercise their civil rights and obligations, to protect the violated right. Adequate real relations and balanced approaches in establishing the duration of the relationship contribute to the stability of civil turnover, eliminate uncertainty about the powers and responsibilities of its participants in the temporal plan, guarantee the possibility of timely legal protection. Thus, the terms ensure the strengthening of contractual discipline, stimulate the activity of contractors in civil relations in the exercise of their subjective rights and legal obligations, guarantee control over the fulfillment of obligations.

The variety of obligatory property relations and the peculiarities of their course in time require a certain classification of civil law terms, which mediate certain relationships, determine the time of realization of the subjective right due to the person and fulfillment of legal obligation, which are part of the material obligation. knitting. This should take into account not only the temporal characteristics of the regulatory obligation, but also the protective, which arises after the violation of subjective law. The temporal characteristics of the existence and implementation of the protective powers of their bearer, including the substantive right to sue (claim) are very important and relevant. This provides an opportunity to properly assess the legal nature, meaning and place of time in the process of acquisition, implementation and protection of subjective civil rights. Unfortunately, the scientific study of the terms of protection of violated subjective rights of the person, mainly, is reduced to the analysis of the emergence, implementation and termination of only one of the protective mechanisms - claims. Meanwhile, protective legal relations arising from the violation of the regulatory substantive law of a person may be implemented out of court. We must state that serious scientific research on the temporal features of this issue has not been conducted in the civil literature. From a methodological point of view, it is difficult to agree with this. This is largely due to an underestimation of the severity of the problem or even a lack of understanding of the importance of relevant civil relations. That is why, for example, for many years the mechanism of application of operative methods of influencing the offender was regulated by case law, which, in turn, quite carefully and often ambiguously reflected the application of such measures, including in the temporal dimension.

The legislator, in determining the temporal factors of certain obligatory material relations, often indicates the appropriateness of their implementation, which should be manifested in the timeliness of the obligation. However, the law stipulates that the duration of a particular legal 
relationship may be indefinite, provided that it does not conflict with the substance of the obligation. Therefore, the most common term for terms, the duration of which is not directly established, is the term "reasonable". For domestic legislation, such an approach to resolving the issue is quite symptomatic. The concepts of reasonableness, as well as good faith and justice, are one of the fundamental principles of civil law (Article 3 of the $\mathrm{CCU})$. But it is reason that is more used to characterize certain manifestations of proper behavior over time. It means that the duration of legal relations should be established taking into account the prudence of the participants, their common sense, expediency and conscious use of concepts, based on the nature and content of the mediated phenomena.

In fact, a reasonable period belongs to the category of definite, but its definiteness is not manifested in regulations or in agreement of the parties, but is determined based on business practices, analogies, etc., ie is the usual duration for such relationships in the territory where they occur. A reasonable period of time is the minimum period of time necessary for the debtor to fulfill his obligation or exercise a subjective right by the active actions of the creditor in specific circumstances that have developed in a particular legal relationship. Life shows that in this context, the development of legal ideology is directed from maximum legal positivism to an increasingly broad judicial judgment. In fact, only case law develops criteria of reasonableness, good faith and fair behavior of participants in material turnover. However, in order to avoid possible discrepancies in this issue, it is necessary from time to time to generalize law enforcement developments in this area.

From the point of view of modern researchers, social time is, first of all, a social institution, a way of measuring and organizing real life, its development, change. Its characteristics have a multilevel subjective essence, as they apply to the individual, and social groups, and society as a whole. It has almost all the main temporal features of physical time as a manifestation of the existence of matter: heterogeneity, sequence, objectivesubjective nature, length, duration, irreversibility, continuity of past, present and future, relativity, uneven pace and rhythm ${ }^{31}$. The social aspect of time is to ensure its appropriate distribution in order to achieve an effective balance between production periods, training, free time for personal intellectual development, socio-political activities and more. This should be aimed at achieving the appropriate level of development of society, meets its needs. According to the concept of planar time, the main means of implementing

${ }^{31}$ Горбунов В.Е. Социологические аспекты социального времени в современном российском обществе : дис. ... канд. социол. наук : 22.00.01. Саратов, 2001. C. $149-150$. 
this task are saving time and planning its distribution in different areas of activity. On the other hand, a particular person must also carry out such an orientation of his time so that his economic and social needs can be best met and meet the requirements of those around him.

As we can see, the socialization of time in the context of the historical progress of society is aimed at achieving a certain effect from the organization of the use of time. At the same time there is a certain change in its meaning and social functions, the temporal influence is directed to the coordination, streamlining, orientation of relevant processes, emphasis is placed on the interconnectedness and validity of necessary and free time, based on their economic conditionality. Thus, according to G.E. Zborovsky, social time is a form of social life in which the decomposition of human activity in terms of its duration within individual socio-economic formations and in the process of all historical development ${ }^{32}$. Indeed, the time course in its socio-historical meaning is a spatio-temporal organization of society under the influence of ongoing economic and social processes and depends on their sequence, duration of repetition, rhythm and so on.

Personal-temporal issues in the context of its attachment to social processes have now become significantly relevant. It is believed that personal time includes essentially different mental elements, which, depending on the specific circumstances and internal factors of the subject occur on a conscious, subconscious or superconscious level. In particular, the elements of such a synthesis can be called the time of perception of others, the time of contemplation and impressions, time of activity, time of reflection and time of creation ${ }^{33}$. Man himself distributes and plans his personal time, and yet he is certainly influenced by the dynamics and rhythm of social processes. The concept of social time is aimed at the rational organization of the relationship between social and personal time, the elimination of contradictions between them, the identification of priority areas of socially necessary time. V.I. Vernadsky pointed out that the sociality of time should be especially evident in periods of history associated with certain turning points, such as the intensification of economic, cultural, political processes ${ }^{34}$. It is at such moments in history that the greatest compaction of time takes place, and thus in society there is an awareness of the need to organize life taking into account its adequate temporal

32 Зборовский Г.Е. Пространство и время как формы социального бытия. Свердловск : Юрид. ин-тут, 1974. С. 14.

${ }^{33}$ Ковалев В.И. Личностное время как предмет психологического исследования. Психология личности и время. Тезисы докл. и сообщ. Всесоюзной научнотеоретической конф. Черновцы, 1991. Т. 1. С. 4-7.

34 Вернадский В.И. Философские мысли натуралиста. Москва: Наука. 1988. C. 297-299. 
regulation. Today in a market economy we can observe a significant increase in social activation of all spheres of life. Social processes have now become more dynamic, the rhythm of their course has increased significantly. On the other hand, the social value of time has increased significantly. In view of this, there is a need to create time budgets that would adequately take into account the nature and intensity of life, ensure the rational use of working or leisure time.

Such research, in fact, is reduced to the analysis of the actual use of time by individual organizations and individuals in different regions within a certain profile of their activities. As a result of studying and processing of the received data the reasons of loss of time are established, the most rational, expedient and economically favorable temporal characteristics of these or those social relations are developed: in the field of commodity production and circulation, training, life, education, culture, health, public activity, etc. The general socio-economic consequence may be the redistribution of structural time in favor of the latest energy-efficient industries, investment-attractive technologies, training within educational activities, youth education, etc. As for the regulation of social time of a particular individual, then here we can talk about the most effective use (consolidation) of time through organizational measures, improving education, leisure. Thus, the optimality of social time for a community is aimed at forming a new direction of thinking, activities to regulate changes in social life, taking into account the role of the individual in society. Therefore, we should agree with the opinion expressed in the literature that the concept of social time is not covered only by the content of human social activity. It also includes the entire range of technical and organizational measures, all done by a person to save time or to expand creative opportunities $^{35}$.

As already mentioned, today serious attention is paid to the analysis of the social orientation of time. At present, a significant number of seemingly purely theoretical studies of the time factor, which should take into account only scientific tools, nevertheless carry a socio-psychological burden, which is generated by the sociality of time. After all, man as an element of society only through his activities realizes the true meaning of time. Being at the first stages of historical progress quite dependent on natural cyclical processes, socio-historical time in the future increasingly begins to reflect the sequence, recurrence, duration and pace of social phenomena. The development of mankind is increasingly displacing the natural and general

${ }^{35}$ Артемов В. Социальное время: предвидение, исследовательски-прикладная и планово-управленческая практика. Телескоп: Журнал социологических и маркетинговых исследований. 2008. № 5. С. 18. 
scientific factors of knowledge of the temporal essence of existence, instead increasing the importance of the social factor in establishing the spatiotemporal relationships of different communities of people. This indicates an increasing dependence of the temporal organization on the spatio-temporal construction of the community, society, state and so on. Therefore, it is quite natural to pose the problem of studying the social characteristics of time from the standpoint of its impact on the existence, functioning and change of social relations.

\section{The social significance of time as a phenomenon that determines the progress of society}

From the point of view of psychology, the ontogenesis of an individual is considered as the unity of biological and social in the process of its development. Based on this, we can talk about the temporal structures of man as an individual, personality and subject of activity. Each of these levels of temporal relations corresponds to its own aspect of research. For example, at the psychophysical level, the question of human adaptation to the current system is studied, which allows for proper orientation in the environment. The psychological direction studies the individual features of the perception of time, for example, as compressed or stretched, empty or saturated, flowing smoothly or abruptly. Finally, personal-temporal issues relate to the temporal organization of an adult's consciousness, behavior during the implementation of individual and group activities and communication, which defines such a category as a way of life ${ }^{36}$.

A person can be aware of time, feel the rhythm of its course and change. At the same time, certain temporal modes of physiological, mental and other life processes are not controlled by an individual. Scientists have long established that our body does not function in different ways at different times of the year. In the literature it is customary to talk about the existence of the so-called biological clock of man. Its activity, ie the countdown of internal time, is influenced by both external, in particular, natural manifestations, and physiological factors, such as cyclical cardiac activity and metabolic processes. In science, the opinion is expressed that the subjective perception of time is due to the duration of internal biological processes, which is clearly defined for each person's individual "step", which averages $0.87-0.89$ seconds $^{37}$. The concept of homeostasis of the

36 Ковалев В.И. Личностное время как предмет психологического исследования. Психология личности и время. Тезисы докл. и сообщ. Всесоюзной научнотеоретической конф. Черновцы, 1991. Т. 1. С. 6.

${ }^{37}$ Цуканов Б.И. Анализ ошибки восприятия длительности. Вопросы психологии. 1985. № 3. С. 150. 
organism testifies to the individuality of temporal motion. Man perceives real time through the speed (biorhythms) of functional processes that take place in his body, because in nature there are subjects of different functionally symmetric groups that respond to changes in the environment differently. The specifics of biological time and space were studied, in particular, V.I. Vernadsky ${ }^{38}$. He found that the temporal characteristics of human life itself are closely related to the speed of functional processes in the body. If these processes are accelerated, the person lives faster, and vice versa. Therefore, based on these speed parameters, we observe different rates of development and aging of organisms.

The possibility of adequate determination of temporal segments, adaptation to real time, is also influenced by conditioned-reflex feelings of a person, his age and emotional features, content, intensity and nature of activities $^{39}$. In particular, children and adolescents tend to overestimate time intervals, while adults tend to reverse the trend. Time seems to pass very quickly if a person has been engaged in various and interesting activities for a certain period of time, but the memories of these events seem to be quite long. Instead, the period seems long, and subsequent impressions - short, when time was not filled with important events ${ }^{40}$. If a certain phenomenon is emotionally assessed by the subject negatively, and the level of personal anxiety increases, it helps to prolong the time in his perception. Conversely, when the level of anxiety decreases, if time is filled with events with a positive emotional color, the time in a person's experiences is reduced. From the point of view of individual researchers, differences in the perception and experience of time in different categories of people may be based on individual characteristics of the brain.

Man is aware not of time itself, but of its movement, change. It is because of the change in time observed by the subject that its definition has been given in the literature. Thus, S. Askoldov pointed out that change is the root or essence of time. Such a change expresses in human perception the unity of the past, present and future, and this unity occurs only in consciousness or through consciousness. Change or, what is the same, time is first of all a state of the soul, it is the so-called psychological time, which has its individuality, subjectivity and in this sense relativity ${ }^{41}$. Indeed, the understanding of the concept of time and its flow arose in man during his

38 Вернадский В.И. Проблема времени в современной науке. Известия АН СССР. 1932 г. № 4. 7-я серия. ОМЕН. С. 536.

39 Москвин В.А., Попович В.В. Философско-психологические аспекты исследования категории времени. Credo. 1998. № 6(12). С. 4.

40 Джемс У. Психология / Ред. Л.А. Петровская. Москва : Педагогика, 1991. C. 181 .

${ }^{41}$ Аскольдов С. Время и его преодоление. Мысль. 1922. № 3. С. 81-82. 
social life, thus defining the collective nature of time as a rhythm. Time is closely connected with all human activity, both physical and intellectual, it is manifested in the influence of the past on the present and the future, in connection with time and true existence, but most characterizes human activity for the future.

As a result of numerous studies, scientists have found that psychological time, as a rule, does not coincide with chronological. In this context, it should be noted such an essential feature of time as its relativity. We have already discussed this characteristic when considering the study of time in mechanics and Einstein's theory. However, temporal relativity is also inherent in the subject's internal time. It is manifested in the different perceptions of time by different people due to differences in their mental state. For example, one person under the same conditions defines for himself a certain range of the present, which he perceives as a period of existing existence, while another perceives it in the second dimension almost as a moment. From the point of view of the causal scientific model, it is as a result of personal experience of the defining relationships between the main events of life that psychological time is formed. Hence the determinism of human life, according to which not only previous events determine the next (determination of the past), but also subsequent goals and desired results determine previous actions (determination of the future). Therefore, the interaction of psychological categories of past, present and future is presented as the ratio of realized connections between events of chronological past, actual connections between events of past and future that continue, and potential connections between subsequent chronological events $^{42}$.

It is believed that the principles of the study of social time were initiated by E. Durkheim. In modern literature, issues of social time are also covered quite widely ${ }^{43,44}$. This definition (in a broad sense) mainly means the form of existence of society in close connection with the course, duration and change of historical processes in view of human activity. In this context, social time in different periods is characterized by uneven flow, taking into account the unequal duration of socio-historical processes, changes in the intensity of public life and work, the consolidation of the schedule of events and so on. In a narrower sense, the concept of social time characterizes the

${ }^{42}$ Головаха Е.И., Кроник А.А. Понятие психологического времени. Категории материалистической диалектики в психологии / Под ред. Л.И. Анциферовой. Москва : Наука, 1988. С. 199-213.

43 Артемов В.А. Социальное время: проблемы изучения и использования. Новосибирск : Наука. Сибирское отделение, 1987. 238 с.

44 Лой А.Н., Шинкарук Е.В. Время как категория социально-исторического бытия. Вопросы фил. 1979. № 12. С. 73-86. 
temporal features of individual human existence. The latter largely depend on personal perception and awareness of time, distribution and orientation of temporal values, the development of strategies. This, in turn, is associated with a number of individually identifying characteristics of a person, such as the level of his education and intellectual abilities, stereotypes of behavior, socio-cultural characteristics, emotional manifestations. Thus, subjective perception is manifested through such factors as personal sense of time, image of time, experience of time, value of time, etc., which are formed based on the inner experience of the individual, the degree of his emotionality and assessment of their significance.

Thus, social time should focus on the content and nature of individual indicators of space and time of specific people - members of society, which in turn are formed under the influence of psychophysical and biological personality factors. As rightly noted by PA Sorokin, social time can (and should) be defined in its own coordinate system, as a change or movement of social phenomena through other phenomena, taken as a starting point ${ }^{45}$. Each person has his own individual space and time, which are perceived by his consciousness and direct further mental activity. At the same time, within the assessment of social time in terms of its impact on the individual life of a particular person for different categories of the population, there are serious differences in the organization and organization of personal time. For example, we must note the relativity of its course in different stages of life: in childhood, adolescence, adulthood or old age. Each of these periods has its own values. For example, an elderly person tries to make time more voluminous, to use it more rationally, while the "waste" of time is typical of young people. It should also be borne in mind that the rapid development of mankind in recent years has contributed to a significant complication of the relationship within the structure of social space-time organization. In particular, we must take into account not only the objective economic and political and legal factors that form this structure, but also the inverse subjective influence of man himself. For example, individual actions or objects created by us also directly or indirectly affect the structuring of society, its organization.

\section{CONCLUSIONS}

An individual, performing certain functions as a member of the community, conducts its activities in time, social relations of different institutions also have temporal characteristics. As participants in various relationships in society and with each other, people not only know but also

45 Sorokin P., Merton R. Social time. A methodological and functional analysis. American Journal of Sociology. 1937. № 5. (V. 42). P. 58. 
use time differently. Thus, we can talk about the need and importance of human influence on the process of learning about nature through its connection with it. In this case, social time should focus on the content and nature of individual indicators of space and time of specific people members of society. Personal perceptions related to each person's personal characteristics, such as the actual psychophysical and biological factors inherent in the individual, must be taken into account. The concept of social time is valuable, first of all, because it is designed to ensure the most appropriate and rational organization of the relationship between social and personal time, eliminating contradictions between them, identifying priority areas of socially necessary time.

Being designed as legal relations, specific relationships in society move into the sphere of regulation by legal mechanisms. Thus, when constructing specific material interactions, the parties to the transactions, determining their content, take into account the temporal criteria of the respective subjective rights and obligations, most adequate to their own private or public (if the legislator sets deadlines) needs. And these needs can be determined taking into account the factor of social time. So we can agree with the opinion expressed in the literature that the concept of social time is not covered only by the content of human social activity. It also includes the full range of technical and organizational activities, all done by a person to save time or to expand creativity.

\section{SUMMARY}

This scientific work is devoted to the study of the topical issue of the essence and purpose of social time as a phenomenon that shapes the social perception of the temporal course of the process of organizing human life. Proper organization of time as a social phenomenon provides the most appropriate and rational organization of the relationship between social and personal time, eliminating contradictions between them, identifying priority areas of activity in the most necessary direction for society. Time characterizes not only external to the observer phenomena, it is also inherent in the internal nature of man. Thus, in the sociological aspect, time is considered as one of the phenomena that characterizes the course of processes, relations and interdependencies in the social sphere, hierarchically interconnected. The ontogenesis of an individual is considered as the unity of biological and social in the process of its development, therefore, the temporal structures of man as an individual, personality and subject of activity are necessarily important. The ability of man to influence the objective course of time in general is obvious. Such influence takes the form of regulation of social life. This, of course, does not mean that the passage of time depends on the will and consciousness of man. Spatial-temporal connections are made objectively, but on the basis of human activities. Thus, awareness of the 
content of social existence - human activity, leads to awareness of the forms of this existence - social space and time. Social time measures the duration of social processes and the dynamism of their change. First of all, this influence is manifested through the possibility of setting time limits for the existence of certain subjective rights and rules to adjust the course of certain terms. Man has a conscious attitude to time, he is able to coordinate their activities in certain periods, plan for the future, be aware of their past. Hence the determinism of human life, according to which not only previous events determine the next (determination of the past), but also subsequent goals and desired results determine previous actions (determination of the future). The paper analyzes a significant number of doctrinal studies of the time factor, which relate to the socio-psychological load generated by the sociality of time.

\section{REFERENCES}

1. Барковская А.Ю. Социологическая интерпретация категории «социальное пространство». Вестник Волгоградского государственного университета. Сер. 7. Филос. 2013. № 1(19). С. 49-55.

2. Sorokin P., Merton R. Social time. A methodological and functional analysis. American Journal of Sociology. 1937. № 5 (V. 42). 649 p.

3. Ковалев В.И. Личностное время как предмет психологического исследования. Психология личности и время. Тезисы докл. и сообщ. Всесоюзной научно-теоретической конф. Черновцы, 1991. Т. 1. С. 4-8.

4. Луць В.В. Строки і терміни у цивільному праві : монографія. Київ : Юрінком Інтер, 2013. 320 с.

5. Головаха Е.И., Кроник А.А. Понятие психологического времени. Категории материалистической диалектики в психологии / Под ред. Л. И. Анциферовой. Москва : Наука, 1988. С. 199-234.

6. Савиньи Ф.К. фон. Система современного римского права. Т. I / Пер. с нем. Г. Жигулина ; под ред. О. Кутателадзе, В. Зубаря. Москва : Статут, 2011. $510 \mathrm{c.}$

7. Гуйван П.Д. Теоретичні питання строків у приватному праві : монографія. Харків, Право, 2014. 632 с.

8. Азімов Ч.Н Поняття цивільних правовідносин. Вісник Університету внутрішніх справ. 1999. Вип. 6. С. 18-22.

9. Луць В.В. Сроки в гражданских правоотношениях. Правоведение. 1989. № 1. С. $37-43$.

10. Шовкова О.В. Строки і терміни як категорії цивільного права. Проблеми законності. 2005. Вип. 74. С. 171-176.

11. Горбунов В.Е. Социологические аспекты социального времени в современном российском обществе : дис. ... канд. социол. наук : 22.00.01. Саратов. 2001. 160 c. 
12. Зборовский Г.Е. Пространство и время как формы социального бытия. Свердловск : Юрид. ин-тут, 1974. 222 с.

13. Вернадский В.И. Философские мысли натуралиста. Москва : Наука. 1988. 520 с.

14. Артемов В. Социальное время: предвидение, исследовательскиприкладная и планово-управленческая практика. Телескоп: Журнал социологических и маркетинговых исследований. 2008. № 5. С. 15-20.

15. Цуканов Б.И. Анализ ошибки восприятия длительности. Вопросы психологии. 1985. № 3. С. 149-154.

16. Вернадский В.И. Проблема времени в современной науке. Известия АН СССР. 1932 г. №4. 7-я серия. ОМЕН. С. 511-541.

17. Москвин В.А., Попович В.В. Философско-психологические аспекты исследования категории времени. Credo. 1998. № 6(12). С. 3-5.

18. Джемс У. Психология / Ред. Л.А. Петровская. Москва : Педагогика, 1991. 368 с.

19. Аскольдов С. Время и его преодоление. Мысль. 1922. № 3. C. $80-97$.

20. Артемов В.А. Социальное время: проблемы изучения и использования. Новосибирск : Наука. Сибирское отделение, 1987. $238 \mathrm{c}$.

21. Лой А.Н., Шинкарук Е.В. Время как категория социальноисторического бытия. Bопросы фил. 1979. № 12. С. 73-86.

\section{Information about the author: Guyvan P. D.,}

Candidate of Law, Honored Lawyer of Ukraine, Professor Professor at the Department of Social Sciences and Humanities Poltava Institute of Business of the International Scientific and Technical University named after academician Yuriy Bugay 7, Sinna str., Poltava, 36039, Ukraine 